\title{
Analysis of Motives and Stimulation on Enlistment of Undergraduate Soldiers
}

\author{
Bai Yun \\ College of Basic Military Education, Engineering University of PAP \\ wanghe717@163.com
}

\begin{abstract}
In order to improve the scientific and technological level and reserve the military talents, some researches were conducted to study the motives for the enlistment of undergraduates. Through in-depth study of factors affecting college enlistment, the impact of stimulating on college enlistment is studied to encourage undergraduates to join the army. This study can provide better theoretical support for the grassroots units and practical basis for undergraduate soldier management.
\end{abstract}

Keywords-Undergraduate soldiers; Motives; Stimulation; Enlistment; Army

\section{INTRODUCTION}

At present, military revolution is surging all over the world. High-tech has been continuously used in warfare and has greatly changed the face of war. This has imposed higher requirements on the military's cultural quality. Recruitment of undergraduate to join the army is to promote science and technology, and the urgent requirements of the modernization of military. In general, undergraduates have a good cultural foundation, quick thinking, open vision, strong plasticity. They can help to improve the overall soldiers' quality, and are conducive to the achievement of strengthening the army by relying on science and technology. This is a major measure to transform the formation of military personnel from the source. However, at the meanwhile, we must also soberly see that the motivation for participating in the military is composite for undergraduates due to the long-term influence from all walks of life. ${ }^{[1-3]}$ If lacking of targeted management, some ideological volatility will be inevitably caused to affect their performance after joining the army. It even led to their unwillingness to work in the army for a long time, resulting in the brain drain for the defense construction.

This paper investigates and analyzes the enlistment motives of the undergraduates in army, and proposes corresponding stimulation in order to enhance the awareness of national defense, inspire them to give up civilian pursuits to join the army and serve the country, display their talents on this big stage of the military by incorporating youth dreams and strong military dreams.

\section{ENLISTMENT MOTIVATION OF UNDERGRADUATE SOLDIERS}

There are numerous factors that affect undergraduates' enlistment. According to some interview with the undergraduate soldiers and references, the enlistment motives of undergraduate soldiers are basically divided into the following categories:

\section{A. The increasingly severe situation of employment}

In recent years, the number of undergraduates has continuously increased owing to the expanding enrollment of college and university. Under limited employment opportunities, employment pressures have continued to rise. Especially in some hot industries and positions, there are often dozens of people or even hundreds of people grabbing a position. For some undergraduates who lack their own abilities or who are not well-known in their universities, it is very difficult to find a favorite job ${ }^{[4-6]}$. In the army, there is much opportunity to expand their career space by military university entrance examination, promotion of officers and the other development. If retirement from the army, government will also give preferential treatment in various aspects such as academic bonus and employment placement. In recent years, according to the adjustment of national policies, the salary of the troops has been increasing. Compared with local general work, wage has a great advantage. Therefore, some undergraduates regard the experience of troops as a "springboard" in order to get new options after leaving the army and achieve "curve employment".

\section{B. The improvement of personal quality}

In the survey, many undergraduates are eager to receive education and training from troops, and improving personal quality is also one of the motivations for undergraduates to join the army. They can train strong physique, sharpen the quality of perseverance, establish a positive attitude, learn practical techniques, and cultivate good behavior habits in the army. The ultimate aim was to make him a comprehensive talent with rich experience and a comprehensive quality. 


\section{Positive responses to the country's manhood}

Some undergraduates have worshiped the military and volunteered to join the army since they were young. At the all stage of schooling, through national defense education, students had a certain service sense of domestic defense, and felt glorious if joining the army. Therefore, they actively responded to the country's call and came to the army, which is also the major motive of undergraduates.

Modern media mainly affect undergraduates through military-related film and television work, newspapers, magazines, books, and other cultural products. Through building the lofty spirit of patriotism and the dignity of the Chinese nation, students' awareness of national defense and dedication are enhanced. Through image shaping and scenario rendering, the glorious image of the military and the military is fully shaped. Using a variety of ways has greatly stimulated the patriotic enthusiasm of the undergraduate and their longing for the army, and has laid a solid ideological foundation for them to join the military. This is the main motives for the vast majority of undergraduate soldiers to understand troops and choose to join the army.

\section{National preferential policies}

Now national preferential policies are also one of the reasons to encourage undergraduates to join the army. Firstly, undergraduate soldiers do not worry about the completion of their studies because the colleges arrange them properly. Secondly, there is the policy of returning from the army. Students can return to their original schools and choose to adjust their majors after retiring, and they will be given appropriate tuition fee. Thirdly, affirming the intention of undergraduates, they will be placed as far as possible into the stations with high level of education and strong technical skills to fully utilize their expertise.

\section{STRATEGY AND INCENTIVES}

\section{A. Expanding development space for undergraduate soldiers to provide better prospects}

First of all, it is important to increase the proportion of promotion of officers for undergraduate soldiers. Secondly, at the military level, it is recommended to open up more military and civilian integration so that undergraduate soldiers can have technical advantages after retiring through military training. Finally, it is recommended that the age limit for promotion of officers should be appropriately relaxed to 27 years old. During the interviews and investigations, many undergraduate soldiers were very keen to have a long-term progress in the army. Under the blueprint for the professional development of servicemen, an appropriate relaxation of the age restrictions will allow the military to retain a group of talents with high cultural qualities, which can effectively prevent undergraduate soldiers selecting retiring from the army after the expiry of the period because they suffered a great failure.

\section{B. Providing more professional and self-realizing platforms for undergraduate soldiers}

In the survey, $59.1 \%$ of undergraduate soldiers were aimed at improving the personal quality of the military. They were keen to develop and progress. Therefore, it is recommended that:

The first is to strengthen and improve the management of military grassroots commanders. In many cases, the management of managers is so limited that they are afraid to use undergraduate soldiers who have a strong sense of democracy. Therefore, they can provide more opportunities for undergraduate soldiers by changing the bad phenomenon.

The second is that the ideological dynamics of undergraduate soldiers must be pay attention to tracking. In many cases, the degree of attention and understanding for undergraduate soldiers is not enough to teach them in accordance with their aptitude. Information carriers such as the "undergraduate soldiers Information Base" and " undergraduate soldiers Growth and Progress Resume" can be established to provide a scientific basis for education and training.

The third is that when new recruits get into a new job, they should be positioned according to their professionalism and specialty, and basically do their best. At present, although many undergraduate soldiers have strong abilities, they are not able to fully play their roles due to their professionalism not fitting their position.

The fourth is to increase the proportion of backbones. For those undergraduate soldiers performing outstandingly, they can be assigned as backbones to perform tasks. Those who perform better can be sent to the coaching team or military college as the focus of attention in the promotion.

\section{Improving the status of servicemen and making them a respected profession.}

To increase the status of servicemen and make them become a profession that is respected by all society, thereby this stimulated the enthusiasm of local college students for their devotion to national defense. The following measures can be taken:

First of all, it is possible to increase the publicity and education of university students before their enlistment. Through the establishment of liaison agencies between military and university, they can carry out some activities in this area to strengthen their understanding of the troops before the enlistment of the army, such as organizing heroes to return home. These activities can effectively increase the professional honor and social status of army men, and stimulate the university students' drive and hard work to respond to the national call actively with joining the army and serving the country.

Second, enhance the image of military personnel in the minds of university students. Widely use modern media such as newspapers, film, radio and television, and Internet platforms to develop national defense education. When making good use of these carriers, we must focus on formal 
innovation and make it easy to accept. If you can put military rescue video for disaster relief, earthquake relief, and disposal of riots on large screens in public places, on television, and on the Internet, so that undergraduate students can better understand the dedication and commitment of the military, so that public opinion can be further improved recognition of army man.

Third, the use of military camp interactions, military model demonstrations and other forms of activities can popularize the knowledge of national defense and stimulate the youth enthusiasm to join the army. Large-scale propaganda banners and booths can be set up in the areas with large people flow, and students in the university can be infected by praising the splendid history and glorious traditions of the party and the army and motivating them to build their own merits. At the same time, arrange volunteers to receive consultation and provide convenience for college students who want to join the military.

\section{Improving the existing policies and formulating more preferential policies}

It is proposed to improve existing policies and formulate more preferential policies. The following points may be considered:

Define the attributes of military occupations and policies to protect the welfare of military personnel. With the encouragement of policy adjustments and reforms, the status and social honor of military personnel are better protected. First, we will relax preferential policies for retired undergraduates who have returned to school for professional change and increase their retired benefits, so as to relieve their worry and strengthen their determination to invest in the country and serve the country.

Second, tuition fee should be appropriately reduced. After retiring from the military, for those students who do not want to be back to school, the school should refund the tuition fees that have been paid before the enrollment. Those who wish to go back to school but whose economy is not optimistic may be waived by the school at their own discretion; if the enrolled students have meritorious service, they should be awarded scholarships of different grades depending on the rewards.

Third, preferential policies for retired resettlement have been implemented. First, civil affairs departments at all levels should work closely with relevant parties to promptly establish and improve a hierarchical management responsibility system and earnestly implement preferential policies. The second is to conduct a good job of resettlement, governments at all levels should proceed from reality, further increase the intensity of the resettlement, support college students to self-employment, and earnestly do a good job of protection for retired college students. Third, each pilot university must conscientiously implement the spirit of the notice and effectively implement the preferential policies according to the requirements of the notice. This is also a powerful guarantee that mobilizes additional school-age college students to actively join the army and encourage active college students to serve in peace.

\section{COOPERATION WITH ARMY}

\section{A. Optimizing the structure and the content of the curriculum system}

If Undergraduate soldiers want to own excellent leadership, they must possess rich knowledge of leadership and management. They should have a clear understanding of the psychological and behavioral laws of both leaders and subordinates, and have a correct judgment of the basic ethical norms so that properly handled or well-managed in the face of complex organizational and individual behavior. Therefore, in the course of teaching, we should increase the proportion of leadership management theory knowledge to enhance the students' theoretical ability. Main knowledge from five aspects needs to be strengthened:

First is the scientific knowledge of thinking. From the innovative, logical, systematic and other aspects of thinking, course in logic, philosophy, systems engineering should be set up to cultivate the ability to adapt to the need for leadership. The second is the knowledge of leadership which is the core of the curriculum. It is necessary to establish leadership science and leadership arts, military leadership, and other courses to enrich the theoretical knowledge of students in leadership and form a preliminary sense of leadership and quality. The third is modern management knowledge. In order to raise the level of leadership, we must learn the theory and methods of modern management science, master theoretical tools such as operations research, system theory and learning organization. Through using of modern management science theory, it can guide the work to improve planning, organization, decisionmaking, commanding, coordination and other basic abilities. The Fourth is psychological and behavioral science knowledge. Undergraduate soldiers are the main working objects of people. They must fully grasp the psychological and behavioral characteristics of their work subjects. They must learn basic human psychological characteristics through psychology, organizational behavior and ethics. The fifth is knowledge of force management. Based on the characteristics and requirements of the military, it should be set up military leadership management courses with obvious military characteristics and strong applicability to help trainees adapt to their job requirements, such as the establishment of various regulations for the army, so that trainees can understand common sense of the leadership of the army and ensure legal management.

\section{B. Building a platform for independent study and practical exercise}

To adapt to the needs of the education and teaching methods for undergraduate soldiers in the information age, it must give priority to embodying students' subjectivity. Through mobilizing the students' learning initiative and increasing leadership effectiveness, we can gradually improve the students' memory of observation, inductive deduction, analysis of comprehensive power and judgmental decisionmaking power. In military training, it is necessary to highlight the key role of practice in capacity development, and actively explore and practice comprehensive drills, confrontation 
training, simulation training, military substitute training, field training, and military intensive training. At the same time, it makes great efforts to improve their ability of analyzing problems, scientific decision-making and organization and command ability.

In the field of non-course teaching, through the guidance of instructors and student-led methods, we organize and conduct a wide variety of group activities such as research competitions, sports clubs, and art festivals, so that the students clearly identify their positioning and responsibility in the participating of organizing activities. Then they can master the skills of communication and collaboration with others, improve self-confidence, self-discipline and willpower, and gradually develop the ability to teamwork, planning and coordination and accurate implementation.

\section{Building a training environment that is close to the command position of troops}

In the generation process of leadership, the impact of environmental factors is very important. We must try our best to shorten the environmental differences between colleges and troops, and shorten the period of adaptation for the graduates in the new post. In the practice of trainee leadership training, it is necessary to fully create a realistic military training environment and simulate the management activities of the ministry (division) team to improve their familiarity with the army management positions. On the basis of achieving basic physical fitness and skills training standards, military training should also enrich the objectives of training students' military accomplishments, teamwork, and leadership management capabilities. Through extending the scope of field training, improving training standards and strength, trainees will have the overload pressure from physiological and psychological in a strange and difficult environment. It can hone their will quality, cultivate spirit of solidarity and mutual assistance, be bold in adventurous and enterprising, and be responsible for the team. Further, it can improve their ability to calmly think and judge correctly under complex environment. In addition, the enriching of experience for teachers and trainee team cadres in the colleges should be focused on. Teachers will be regularly selected to perform duties in the military, and outstanding military officers will be selected to serve in the colleges, so that it always maintains the orderly flow between colleges and military. It is necessary to build high-quality cultural teaching venues and facilities with military camp features that can meet the needs of teaching and training.

\section{CONCLUSION}

Through interviews with university students and questionnaire surveys, the author believes that the five factors that affect the enlistment of college students into the army are the military career development prospects, the promotion of personal qualities, the active response to the national call, the national preferential policies and the impact of modern media. Further, from the motivation of university students joining the military to find a solution, the purpose is tantamount to further encourage college students to carry their pens, and provide effective theoretical support and practical basis for grassroots troops to better manage college students.

\section{REFERENCES}

[1] WANG Junxia. Research on the cultivation of students' leadership ability in military university, Changsha: National University of Defense Technology, 2008.

[2] WANG Rui, LI Longmei, ZHOU Hao, ZHAO Wei. Analysis on the Training of Military Academy Students' Management Ability. The Journal of Higher Education, 2012, 3(02): 45-48.

[3] Yang Xiaodan. Energetically promote the talent strategy project - speed up the cultivation of new types of military personnel. Naval Academy Education. 2005, 15(02): 32-35.

[4] WANG Junxia. Research on the cultivation of students' leadership ability in military university, Changsha: National University of Defense Technology, 2008.

[5] WANG Rui, LI Longmei, ZHOU Hao, ZHAO Wei. Analysis on the Training of Military Academy Students' Management Ability. The Journal of Higher Education, 2012, 3(02): 45-48.

[6] Yang Xiaodan. Energetically promote the talent strategy project - speed up the cultivation of new types of military personnel. Naval Academy Education. 2005, 15(02): 32-35. 